\title{
Village Community Opinion to Selection of Single Regional Candidates
}

\author{
Diah Fatma Sjoraida \\ Faculty of Communication Science \\ Padjadjaran University \\ Bandung, Indonesia \\ diah.fatma@unpad.ac.id
}

\author{
R K Anwar \\ Faculty of Communication Science \\ Padjadjaran University \\ Bandung, Indonesia
}

\author{
G Amatunnisa \\ School of Business and Management \\ Institute of Technology Bandung \\ Bandung, Indonesia
}

\begin{abstract}
The purpose of this study was to find out how the perception of the rural community regarding the election with a single candidate, and to find out how the level of society political participation in the poll with an only candidate in Tasikmalaya Regency. With descriptive and qualitative methods, it was found that the collective behavior of the community influenced the level of political participation of voters in rural areas in Tasikmalaya District elections. The attitude of voters, in general, stated that they did not agree on simultaneous polls with a single candidate, while some agreed. His political participation was almost included in the level of passive involvement and the participation pyramid involved in the apolitical category. When the pilkada acts or activities of the community only obey, accept and carry out every government decision, the voters inevitably follow the government's decision even though they tend to disagree with the existence of a single candidate.
\end{abstract}

Abstract-Village Community Opinion, Single Regional Candidate, Democratic Election

\section{INTRODUCTION}

Political participation in a country that adheres to a democratic system is one of the indicators of implementation in the implementation of the highest legitimate state power by the people (people's sovereignty), which is manifested in their involvement in the Democratic Party (Election). Political participation is also an essential aspect of democratic state order and is a characteristic of political modernization. The higher level of political participation indicates that people follow and understand and involve themselves in state activities. Conversely, if the level of community participation is low, it suggests that people lack appreciation or interest in state problems and exercises.

The problem for a rational choice theory with community participation is that if personal interests are the only basis for political action, how we can explain the amount of time and effort that citizens pour out for membership in civic associations without pay. Sociological and psychological factors strongly influence community participation, where sociological characteristics, family background, socialization, and life experience are variables that affect the level of political involvement in the elections. And in reality some voters change their political choices when they give their voting rights, there are also those who come to the polling station but suddenly do not give their votes (abstentions).

This is due to the dependence on certain political events that can change a person's political preferences, and there are situational factors that occur that influence the political participation of the community. The situational factor can be in the form of political issues in nominated candidates, in which this political issue is an important consideration in which voters will make choices based on an assessment of the political problems that occur. This means that voters can make their decisions based on rational factors.

By using rational choice theory, it can be concluded that voters can use their rationality in determining their choice of candidates who are advancing in the elections. Some voters make a valid assessment of the party's and candidate's vision, mission and work program. Rational voters have sufficient motivation, principles, knowledge, and information. Their actions are not coincidence or habit alone and not solely for personal gain, but also for the public interest, according to their logical thoughts and considerations.

Political participation of the community, using rationality in elections also arises when they think of what benefits they will get when they use their voting rights. Districts and candidates for regional heads both have an interest in resources, namely money and political positions which influence each other. Candidates for regional heads provide offers that promise benefits to the community, and the community also provides in the form of votes to win the candidate pairs. So that finally the community and prospective regional heads are involved in a relationship to fulfill their respective interests.

The low level of people's political participation is reflected in the attitude of the white group or commonly called abstentions in the general election. And in the case of the presence of a single candidate in the implementation of the votes in Tasikmalaya District which led to polemics and also allegedly affected political participation in the implementation of the elections.

On 9 December 2015 Indonesia held a Regional Head Election simultaneously. One of them is the election held in Tasikmalaya Regency. The problem and become a polemic in the pilkada is that only one contestant is available or there is only one single candidate who nominates as a candidate for Regent and Deputy Regent for Tasikmalaya Regency, namely Mr. H. Uu Ruzhanul Ulum and H. Ade Sugianto who registered in the Pilkada. So that in the election the system used is a referendum, which is applying the option concept, between agreeing and disagreeing on the ballot, if the majority votes agree then automatically Mr. Uu Ruzhanul Ulum and Ade Sugianto will go back to become the Regent and Deputy Regent of Tasikmalaya Regency and vice versa.

The existence of a single candidate in the implementation of the elections in Tasikmalaya Regency is one of the factors 
decreasing the political participation of the people in Tasikmalaya Regency. As happened in Sukarapih Village, Sukarame District, Tasikmalaya Regency where there are 4,253 votes, 1,586 abstentions, the data shows that a decrease in the level of political participation of the people in Sukarapih Village because the number of abstentions was quite high in the regional head elections if compared to the previous election.

This shows that the existence of a single candidate will have an impact on the level of political participation of the community. In addition to the many facts that lead to a process of misfortune in a society that creates a crisis of trust from the public to state institutions, which in turn leads to a more delicate overall democratic process. The thing that happened in Sukarapih and Sodonghilir villages was political apathy among the people. Of course, this is very dangerous because if this continues to occur, it will eliminate the political control function of the community against the existing political institutions. The community no longer cares about the behavior of the political elite who do not side with them.[1] The political apathy that occurs is a reflection of awareness that politics for society is not the whole of life. As a result, this condition is the reason for the decline in political participation in the villages of Sukarapih and Sodonghilir.

Political participation of the community with the presence of a single candidate in Tasikmalaya Regency, especially in Sukarapih Village, Sukarame District and Sodonghilir Village, Tasikmalaya Regency, is interesting to study. Because indeed with the existence of a single candidate to be a polemic for voters in Sukarapih Village, so that it has an impact on the level of community participation, especially in state activities, namely the regional head general election in Tasikmalaya District. The level of political involvement of the people in the practice of democracy in Indonesia must remain high and not only stop at the election but must continue, because the level of political participation of the people is a means of controlling the community against the political elite in formulating policies and realizing prosperity for the people.[2]

\section{METHODOLOGY}

This study uses a qualitative approach. Qualitative research is a research procedure that uses descriptive data in the form of written or verbal words from people and observable behavior.[3] In the process of this research carried out using descriptive methods, which have characteristics such as formulating attention to the problems that exist at the time this research was conducted or the actual problem, and describe the facts about the problem being investigated accompanied by rational interpretation. This method is characterized by the data obtained first prepared, explained, then analyzed.[4]

The method used in this research is a descriptive method, and the approach used is a qualitative approach. Primary data sources are the people of Sukarapih Village and Sodonghilir Village who have the right to vote, based on the background of their position in society, work, education, and age. Interview with the head of the Tasikmalaya District Election Commission, with the secretary of the Sukarapih Village and the former chairman of the PPS of Sodonghilir Village. Data collection techniques are observation, interview, and literature study. Furthermore, the data analysis used by the Miles and
Habermas model is data reduction, data presentation, and conclusion drawing/verification.

\section{RESULT AND DISCUSSION}

On December 9, 2015, the simultaneous local elections were held throughout Indonesia, Tasikmalaya District became one of the regions that participated in the simultaneous elections. What is interesting from the polls in Tasikmalaya Regency, namely the implementation is followed by only one single candidate, thus in the implementation of the Pilkada in Tasikmalaya Regency is different from the Pilkada-Pilkada conducted in the previous period, this certainly has an impact on the implementation mechanism, and also on participation community towards organizing the election.

Although only one single candidate is followed, the elections in Tasikmalaya Regency can be held based on the decision of the Constitutional Court Number: 100 / PUU-IIIV / 2015 dated September 29, 2015, concerning 1 (one) candidate pair in the election of Regional Heads and Deputies Regional Head simultaneously in 2015. Then the explanation is as follows:

1) Please immediately carry out the decision of the Constitutional Court and continue the stages of the election that has ceased, taking the following steps:

a) preparing for the decision to revoke the postponement of the phases of the election of the Regent and Deputy Regent in 2105;

b) determining changes in arrangements regarding the steps, program, and schedule for the election of the 2015 Bupati and Deputy Regent, by continuing to take into account on 9 December 2015 as voting;

c) for regions that have terminated PPK and PPS to prepare the appointment/reappointment of PPK and PPS that still fulfill the requirements;

d) adjusting the process of procurement of goods and services for logistical needs at the selection stage; and

e) re-coordinate with the Regional Government related to the financing or the Pilkada grant.

2) Preparation and stipulation of changes in decisions regarding the stages, program and schedule for the election of the 2015 Regent and Deputy Regent number 1 letter $b$, still taking into account the time requirements as stipulated in KPU regulation No. 2 of 2015

3) Technical matters that affect the provisions governing the electoral stage will immediately specify a KPU regulation that specifically applies to regions with only one candidate pair.

4) Requested by the KPU of the Province of East Nusa Tenggara, West Java, and East Java to supervise the KPU of East Tengah Utara Regency, Tasikmalaya Regency and Blitar Regency regarding this matter and immediately report to the KPU.

Based on the decision of the Constitutional Court above, even though only one single candidate in the Pilkada in Tasikmalaya Regency can be followed. This also happened in North Central Timor Regency and Blitar Regency. In this case to anticipate the low level of community participation in 
the Pilkada, here social institutions including the Election Commission, Political Parties, Mass Media and Mass Organizations have a significant role in increasing community participation, for the successful implementation of elections in Tasikmalaya District.

Social institutions, for example, KPU have played a major role in increasing community participation, because of the role of social institutions to give positive and negative sanctions to the community so that they influence the community to determine whether or not to participate. KPUD has the role of increasing the political participation of the public to exercise their right to vote., as stated in Law Number 15 of 2011 concerning the implementation of Article 10 of the general election which states that: "One of the authorities of Regency / City KPU is to organize socialization and holding general elections and/or related duties and authority of Regency / City KPU to the public." KPUD increases political participation through socialization and political education of the community.

In order to increase the political participation of the people in Tasikmalaya District, the KPU has optimized the election socialization with a single candidate, the socialization carried out by the KPU is tiered, and first the socialization is carried out at the District level, then to the District level, then finally to the Village level. In the lead-up to the 2015 elections in Sukarapih Village, it was quite good in its socialization because it was assisted by friends from the pesantren in socialization to increase community participation.

Based on the decision of the Constitutional Court No.100 / PUU-XIII / 2015, Tasikmalaya District carried out the election with a single candidate mechanism. The couples who advanced in this simultaneous election were the incumbent pair Uu Ruzhanul Ulum and Ade Sugianto who were supported by PKS, PDIP and PAN parties. While the background of a single candidate, based on DNH's explanation, is that the first political party sees the pair Uu Ruzhanul Ulum and Ade Sugianto as incumbent couples, the second because of the decision of the Constitutional Court (MK) which states that if there are councilors, PNS or POLRI nominating as a regent, he must resign so that this condition is considered severe. Moreover, Uu Ruzhanul Ulum and Ade Sugianto are incumbent couples so that others are likely to think again because to nominate their terms is considered difficult especially having to leave office. So that this factor became a polemic for Tasikmalaya Regency in this regional head election.

In the simultaneous regional elections held on December 9, 2015, despite a polemic in Tasikmalaya Regency, namely with the existence of a single candidate but the pair $\mathrm{Uu}$ Ruzhanul Ulum and Ade Sugianto managed to win the election again as the Regent and Deputy Regent in Tasikmalaya Regency. The results of the vote recapitulation of the pair Uu Ruzhanul Ulum and Ade Sugianto at the Tasikmalaya Regency level are as follows:
Table 1. The results of the Vote Recapitulation the Tasikmalaya Regency Level

\begin{tabular}{lc}
\hline Valid Voice agrees & $500.908(67,35 \%)$ \\
\hline Valid Voice Disagree & $242.865(32,65 \%)$ \\
Valid Voice Number & 743.773 Voice \\
Invalid Voice Number & $66.895(08,25 \%)$ \\
$\begin{array}{lc}\text { Legitimate and Unauthorized } \\
\text { Amount }\end{array}$ & 810.668 Voice \\
Participation Rate & $60,33 \%$ \\
Number of DPT & 1.343 .640 Voters
\end{tabular}

Source: Archive of KPU of Tasikmalaya Regency in 2015

Based on the results of the recapitulation of the above votes, in Tasikmalaya District, the regional head election participation rate was $60.33 \%$. According to Mr. DNH as chairman of the Tasikmalaya District Election Commission, there was a decline in the level of community participation when compared with the previous elections, for example, the Pileg and Pilpres, whose participation was more than $70 \%$. So in this single candidate election, there was a decrease in the participation rate of $10 \%$, when compared to Blitar and North Central Timor, in Tasik District the participation was the lowest. In Blitar and in the North East, participation was more than $60 \%$. This decline occurred due to various factors that underlie it, including the saturation that occurs in the community because they consider the elections or general elections to not bring significant changes to people's lives, especially in economics, and social welfare, then with the existence of a single candidate is considered less attractive because only there is one candidate pair, then many other factors such as the number of people who work and those who study outside the area so that it is difficult to take the time to go home to distribute their voting rights, indeed it has been closed but still has no effect."

\section{1) Rural Community Opinion}

Regional Head Elections or Pilkada are regional head elections held by the General Election Commission and are followed directly by local administrative residents who have fulfilled the requirements. Regional head elections are carried out in one package with the election of deputy regional head. Since the enactment of Law Number 32 of 2004 concerning Regional Government, the Regional Head has been directly elected by the people through the election of the Regional Head and Deputy Regional Head or abbreviated as the Regional Election which was first held in June 2005.

$\mathrm{NN}$ has its own perception regarding the election with a single candidate, based on Nisa's statement: "Actually, I disagree if the pair Uu Ruzhanul Ulum and Ade Sugianto become regents again but how come the candidates are just one. When I did simultaneous elections I did not play an active role as a successful team, but I just followed the election process by coming to the polling station to channel my voting rights so my participation was just to vote. " 
In rational choice theory, viewing that individual voters are not determinants in determining their choices because of external factors that influence the direction of their choice. On the contrary, this theory views individual voters as someone who voluntarily or freely determines his choices based on considerations that benefit him. In political participation, people use their rationality to make their choices. According to Dennis Kavanagh stating that rational choice sees picking behavior activities as a product of the calculation between profit and loss.[5][6] This is because voters consider not only the cost of voting and the possibility of their voice influencing the expected results but also the differences from alternatives in the form of choices.

Voters in this approach are assumed to have sufficient motivation, principles, education, knowledge, and information. The political choice they took in the Pilkada was not due to chance or habit but according to logical thinking and consideration. Based on data, education and knowledge possessed by voters decide they have to make their choices with profit and loss considerations to make choices on alternatives that are available to the best and most profitable choices both for their own interests and for the public interest.

So that in reality when the elections took place in Sukarapih and Sodonghilir villages, some voters changed their political choices from one election to another. This phenomenon shows that there are other variables, namely situational factors which also influence the perception of voters when determining their political choices during the election. This is because a voter is not only passive, shackled by sociological characteristics and psychological factors but is an active and free-to-act individual. Theoretically, rational choice theory. Rational choice theory considers that individual voters are not determined individuals in determining their choices because of external factors that influence the direction of their choice. On the contrary, this theory views individual voters as someone who voluntarily or freely determines his choice based on considerations that benefit him. In this case, Evans stated that rational choice theory focuses on individual voters and seeks to explain the decision-making process to choose the party (or candidate) to be elected.[7]

Someone in doing rational action is selfish and all his actions are based on that tendency. They are always looking for efficient ways to achieve their goals. However, this is disputed by functional structural adherents. Because in reality that humans in their political behavior are often irrational, that humans sometimes do not have a firm and stable scale of preferences, and other considerations help determine their attitudes, such as the factors of culture, religion, history, and morality. Human actions are also inspired by what is good and what is possible.

So that, in this case, the researcher saw that the effect of the rationality of the voters of Sukarapih Village community was analyzed using rational choice theory. In simultaneous elections, the public has a perception of the elections with a single candidate and for a candidate pair. If analyzed in rational choice theory, there are three analyzes of macro phenomena that can affect people's perceptions in simultaneous elections with a single candidate in Tasikmalaya District which was implemented on December 9, 2015, namely: collective behavior, norms, and corporate actors.[8]

But in collective behavior, there is an effort to maximize individual interests that do not always cause a system balance. Even though the same thing happened in the simultaneous local elections to maximize its interests, issues arose that influenced voters' political perceptions and choices on the people of Sukarapih Village so that some people did not distribute their voting rights. Because there are collective and individual behaviors that influence the perception that they feel their interests will not be fulfilled even if they choose the single candidate pair. This is based on the consideration of interests.

In simultaneous local elections with this single candidate, the community has different perceptions that are influenced by collective behavior, norms and corporate actors. So that the election this time showed a decrease in the level of political participation of the people because the abstentions reached $38.64 \%$ or as many as 1636 . However, the presence of abstentions or voter absenteeism to polling stations in the elections does not mean that the whole community is apathetic towards political activities, but there are several factors who heard why the Sukarapih village voters did not exercise their voting rights when the simultaneous local elections took place.

With the perception of the public relating to political participation and the motivation to vote related to the identification of voters against candidates in the elections. Particularly in the simultaneous election, the candidates for the candidates for regional head and deputy regional head candidates are proposed. Also, the achievement of the single candidate pair is one of the determinants of voter interest in choosing. This means that the strengths and strengths of candidates and the issues proposed as campaign material become the basis for rational consideration for voters in Sukarapih Village to determine their choice of votes for the single candidate pair.

\section{B. Village Commnity Participation}

Participation influences the legitimacy of the community, namely the way of a government. In a Regional Head Election, the political participation of the people is very influential on the legitimacy of the community to the elected candidate pairs. Every community has their own interests in determining their choices in the elections. The level of community political participation in the election can be seen as a control of the community towards a government, participation as well as the core of democracy, but political participation is also closely related to the fulfillment of the political rights of a citizen.

As a manifestation of the fulfillment of citizens' political rights, there is freedom for every citizen to express their 
opinions and gather. As stated in Article 28 of the 1945 Constitution which states that: "freedom of association and assembly of thoughts with oral or written and so forth, are stipulated in the Law".

Political participation which is a manifestation of the manifestation of popular sovereignty is a very fundamental matter in the democratic process. Participation has a very important meaning in the movement of wheels and democratic systems. If the community has a high level of participation, the political development process will run well, so it will be very meaningful as well as the development of this nation and state. On the contrary, political participation will not mean anything and does not mean at all if participation does not meet the requirements.

Therefore the level of political participation of the people in the general election, including the Election of Regional Heads is very important to be analyzed, in this case concerning the participation of the Sukarapih Village community in the presence of a single candidate in the simultaneous election that was held on 9 December 2015. Low or high a participation is an important factor in the process of the democratic and embodiment of popular sovereignty. The following is data on the number of voters in simultaneous elections with a single candidate in Sukarapih Village, namely:

Table 2. Data on the Number of Voters in the Simultaneous Election in December 2015

\begin{tabular}{lcccccccccc}
\hline Detail & $\mathrm{T}$ & $\mathrm{T}$ & $\mathrm{T}$ & $\mathrm{T}$ & $\mathrm{T}$ & $\mathrm{T}$ & $\mathrm{T}$ & $\mathrm{T}$ & $\mathrm{T}$ & TPS 10 \\
& $\mathrm{P}$ & $\mathrm{P}$ & $\mathrm{P}$ & $\mathrm{P}$ & $\mathrm{P}$ & $\mathrm{P}$ & $\mathrm{P}$ & $\mathrm{P}$ & $\mathrm{P}$ & \\
& $\mathrm{S}$ & $\mathrm{S}$ & $\mathrm{S}$ & $\mathrm{S}$ & $\mathrm{S}$ & $\mathrm{S}$ & $\mathrm{S}$ & $\mathrm{S}$ & $\mathrm{S}$ & \\
& 1 & 2 & 3 & 4 & 5 & 6 & 7 & 8 & 9 & \\
\cline { 2 - 9 } LK & 1 & 1 & 2 & 2 & 2 & 2 & 2 & 2 & 2 & 243 \\
& 4 & 5 & 0 & 0 & 8 & 3 & 3 & 6 & 0 & \\
& 8 & 9 & 2 & 2 & 8 & 2 & 0 & 1 & 2 & \\
PR & 1 & 1 & 1 & 1 & 2 & 2 & 2 & 2 & 2 & 234 \\
& 6 & 4 & 8 & 9 & 6 & 2 & 1 & 4 & 1 & \\
& 4 & 5 & 4 & 5 & 6 & 8 & 1 & 4 & 5 & \\
No. & 3 & 3 & 3 & 3 & 5 & 4 & 4 & 5 & 4 & 477 \\
& 1 & 0 & 8 & 9 & 5 & 6 & 4 & 0 & 1 & \\
& 2 & 4 & 6 & 7 & 4 & 0 & 1 & 5 & 7 & \\
\hline
\end{tabular}

Source: Data from DAA Sukarapih Village 2015

Based on data on the number of voters in simultaneous elections in Sukarapih Village, there were 4,253. Then in the results of the vote acquisition of the candidate pairs $\mathrm{Uu}$ Ruzhanul Ulum and Ade Sugianto in Sukarapih Village, the number of votes did not agree more if compared with the number of votes agreed. Can be seen in the following table:
Table 3. Details of Obtaining Candidates for Candidate Pairs

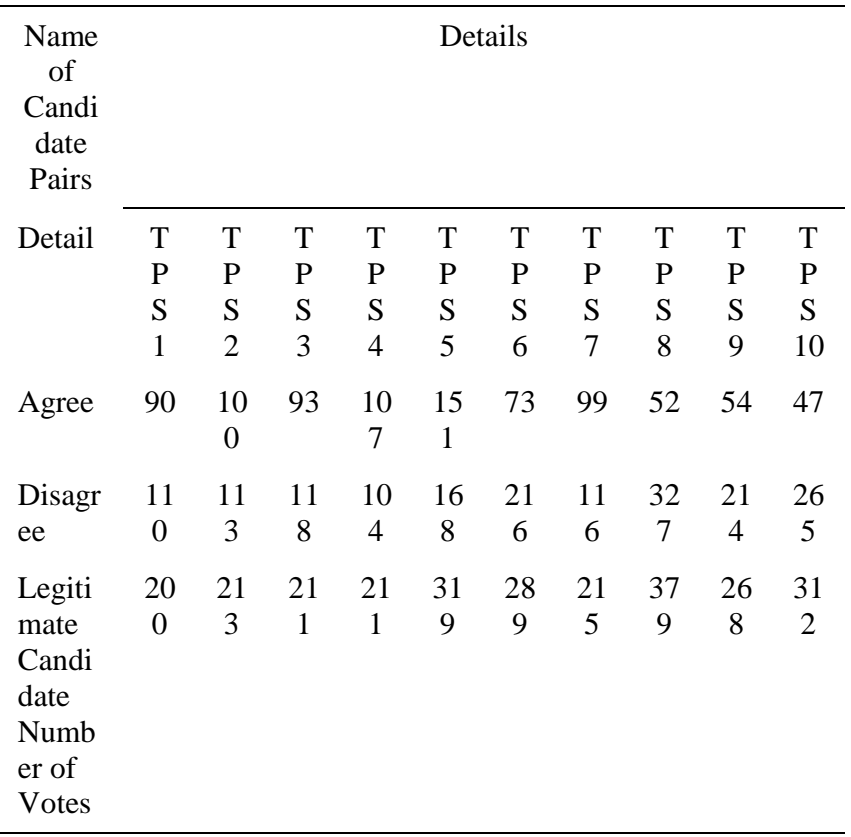

Source: Simultaneous Local Election Vote Data, Sukarapih Village archives in 2015

The number of voters in the Election of Regional Heads in Sukarapih Village is as much as 4,253. Voters represent rational factors that encourage themselves to channel their voting rights. That is, the driving factor in the form of benefits obtained from the choices determined, both parties and candidates. Also, several social and political characteristics have the potential to encourage one's choices, namely: age, gender, social/occupational class, religious groups, and ideological groups.[9]

Based on the data above, it can be explained that 866 votes were agreed, namely $20.36 \%$, while the number of votes disagreed as much as 1,751 , namely $41.17 \%$. From the number of voters of one village as many as 4,253 , and as many as 1636 or around $38.46 \%$ preferring not to come to the polling station to channel their voting rights, this amount is evidence that there is a decrease in the level of political participation of the Sukarapih villagers when compared with the previous year. As IS stated, yesterday's participation around $61.53 \%$ was present, but this number decreased when compared to the previous year, namely in 2014 when the Legislative Election (Pileg) and Presidential Election (Pilpres) whose participation reached $75 \%$.

Based on the presentation from the description of the results of the acquisition of a single candidate pair $\mathrm{Uu}$ Ruzhanul Ulum and Ade Sugianto, the participation of the Sukarapih and Sodonghilir villagers if analyzed based on the degree of political participation, which is described in four categories, namely: 1) the highest pyramids are activists, fulltime party officials or party or interest group leaders. In Sukarapih Village, most of the people are just ordinary people not as party officials or party leaders. So that the Sukarapih villagers are not included in the activist category in the degree 
of political participation; 2) one level below is the participants, namely the people in charge of carrying out the campaign, as active members of a party or interest group, and so on. Sukarapih Village Community is also not included as active participants in the activities of a party; 3) next is the observer group, which orientates itself to attendance at public meetings, following political developments through the mass media, voters in general elections, and others. Sukarapih Village Community can also be said to be an observer group, namely by following political developments through the mass media, and also as voters in general elections; and 4) at the bottom of the pyramid, are apolitical (apathy) people towards political activities.[10]

Based on the analysis using the degree of participation above, the participation of the community of Sukarapih Village and Sodonghilirketika Pilkada simultaneously with the single candidate on December 9, 2015, including the apathy group or passive participation, where the community when doing an activity, in this case, the local election they only obey, accept, and carry out every government decision. Sukarapih villagers inevitably follow government decisions even though they tend to disagree with the existence of a single candidate. Sukarapih Village Community has its perception towards the single candidate pair, Uu Ruzhanul Ulum, and Ade Sugianto so that in this election, the participation of the people decreased and apathy towards the Pilkada with a single candidate in Tasikmalaya Regency.

Whereas if analyzed as a form of activity, participation can be divided into four categories: (a) Apathy, namely people who do not participate and withdraw from the political process; (b) Spectator, that is, people have voted in general elections; (c) Gladiators, namely people who are actively involved in the political process; (d) Critics, namely in the form of non-conventional participation. Can be in the form of petitions, demonstrations, confrontations, and acts of violence.[11]

Based on the form of participation above, the participation of Sukarapih Village community is mostly included in the form of spectator participation. As many as 2,617 voters in Sukarapih Village used their right to vote, and they participated in the election by only voting during the election with a single candidate in Tasikmalaya Regency, namely the couple, Mr. Uu Ruzhanul Ulum and Ade Sugianto. This is done because the election is considered as a form of activity that must be followed because it complies with government regulations, without being actively involved in the political process. In general, the people of Sukarapih Village are ordinary people not from party activists and only a few people are actively involved in political activities, or as members of political parties.

The participation of Sukarapih villagers in 2015 decreased and tended to start apathetic towards Pilkada with a single candidate because of the disappointment of Sukarapih villagers towards the performance and achievements of Pak Uu Ruzhanul Ulum and Mr. Ade Sugianto during their previous leadership period, making the community less enthusiastic and less amenable to the existence of a single candidate. Then in terms of education, economy, social welfare, and the construction of road facilities and infrastructure were not well realized. For example, the road to the Taman Pahlawan KH. Z Musthafa in Sukarapih Village had remained damaged until now when there was road repair it only lasted a few months.

With the existence of this single candidate based on the results of research and interviews with some informants, it did reduce the interest of political participation in the Sukarapih Village community in choosing candidates for the Regent and Deputy Regent. This is because there are different community perceptions about a single candidate, there are many reasons and factors behind why many do not distribute their voting rights because there are less agreeable factors in the Sukarapih village community with a single candidate, in addition, there is a public perception of the incumbent $\mathrm{Uu}$ Ruzhanul Ulum and Ade Sugianto.

Several reasons or factors cause the Sukarapih village community not to exercise their voting rights in the elections with a single candidate. First, some of the people who did not distribute their voting rights were working outside the city. Second, some students study outside the city. Third, some older adults have no chance to come to the polling station but are still on the DPT list. Fourth, some people are truly apathetic. Fifth, there is a busyness that really cannot be left behind. Sixth, there is only one candidate pair in the Pilkada, so there is no variation. Seventh, candidates who are less interested in the community or less calculated by the community so that the community is not enthusiastic and many do not agree with the existence of a single candidate.

There are reasons why someone did not vote when the elections were simultaneous. An informant said: "when I did the Pilkada yesterday I did not come to the polling station and did not distribute my voting rights, not because I was anti but coincidentally when I was on duty in East Kalimantan yesterday, and the location is being inactive and not voting. Because to go home access is far enough and it is not possible to participate in the elections ".

Based on the results of the interviews above, there are indeed a number of factors behind the decline in the level of political participation of the Sukarapih villagers, the decline in the level of community participation not solely due to disagreement with simultaneous elections with a single candidate, but other factors as revealed by Mr. DR, so from various factors are there are many voters who do not distribute their voting rights.

But if while being able and having an opportunity, it should be as a wise society to participate in the electoral process to determine the leader who will lead us. Thus, indirectly we will determine policymakers who will strive for the welfare of society in general. By actively participating in the Pilkada process, as a smart society even though only one candidate we have been able to judge the best and if we are able and willing to listen to the aspirations of the community 
so that the development will be by the wishes of the community. And do not choose candidates who only concern themselves or their groups so that they forget the promises that have been made during the campaign period.

Apart from the individual factors above, social factors originating from outside the individual will also motivate individuals to determine the choice of party or candidate. Trust, social group affiliation, and social identity that grow in the selector become factors of the mobilizer in choosing. For this reason, parties or candidates usually personify themselves as figures that are identical to their beliefs, groups and social identities. The next motivational factor for choosing is related to the issue. This theory rests on the assumption that each voter has some attention to what influences their lives. Issues related to policies and behavior that affect the quality of life of individual citizens. In modern countries, individual citizens depend on policies to encourage the supply of economic, social, cultural, and issue resources related to priority issues that must be addressed to influence the quality of life of citizens.

The issue also relates to priority needs that are urgently met for the same purpose. Individuals based on their experience and understanding will be able to explain crucial issues related to themselves. The issue in question will be related to economic, social, cultural, political and service conditions that have been felt and experienced by citizens. For this reason, some possible issues are identified to determine the direction of voting behavior towards parties and candidates. Both will offer some policy promises during campaigns related to the conditions of citizens. Some issues that may arise include health services and guarantees, education services and guarantees, problems of unemployment, public transportation, environment, budget, business facilities, taxes, protection of traditional arts, and other public issues.

Based on these issues that influence the perception of the community in Sukarapih Village, and with this it can be known the tendency of preference to vote so that it has an impact on the political participation of a voter in Sukarapih Village. Party and candidate programs can be a consideration for choosing. Or, development outcomes that are the attention of individual citizens can also be the basis of individual choice. Ideology and political party affiliation are the next factor that will motivate voters to make choices. Ideological considerations rely on the assumption that individual views and responses to policies are related to elite ideology and political parties.[7]

As the owner of the right to vote in the Election of Regional Heads with the presence of a single candidate, do not let the voting rights be wasted only for a temporary lure, in the sense that we have to cast our votes even if the candidate is only one and the choice is only to agree and disagree. The lack of community actually will make the community difficult by themselves because we do not participate but must follow leaders who do not match what they expect or want. Voter participation in the implementation of elections is necessary, without voter participation, the polls only make it as an object, and one of the criticisms is when the community does not feel possessed and indifferent to the election of the Regional Head with a single candidate.

So the socialization in the election with a single candidate this time must be able to motivate voters to be indifferent even though candidates who register only one pair or a single candidate. The socialization that has been carried out is as much as possible and is carried out in stages. It's just the decline in participation that occurred in Sukarapih Village because of the perception that the election with a single candidate was wrong and some people did not agree.

In fact, in increasing public participation in the elections, it is not solely the responsibility of the Government, but there are three related components, namely the Government or Election Organizers, Political Parties and Communities. The community should also be used as an object in the elections but also given a sizeable role so that there is a sense of ownership of the elections, feeling part of the responsibility in the polls so that they participate fully in the election. One who can provide important understanding and awareness?

Pilkada is motivating with socialization, community political education so that there are a willingness and ability and the community is given the opportunity to participate as much as possible. Also, in the regional head general election, voters' motivation to make their choice on candidates is strongly influenced by voter perceptions of the candidate figure, the perception comes from outside the individual but can also be from within the individual. The popularity of single candidate figures in simultaneous elections can be measured through public perceptions of candidates based on ideological considerations, trust in candidate figures, social identities, programs raised, and so forth. The popularity and public perception of the candidate pair Uu Ruzhanul Ulum and Ade Sugianto explains the feasibility or appropriateness of a figure according to public perception.

According to $\mathrm{MH}$, when he did the election he did not vote because he worked in Bogor and to take time to go home was felt responsible because the long distance and to go home one day would feel very tired. In contrast to the narrative from SS as a beginner voter who prefers abstentions rather than to channel his voting rights. According to him, this single candidate was less attractive because there was no choice, and did not agree because he heard and followed his family, and friends who did not agree with the pair Uu Ruzhanul Ulum and Ade Sugianto.

The importance of socialization and political education, especially for beginner voters, as a direction and motivation to continue to participate actively. Because socialization and civic education did not necessarily be able to encourage the community to participate optimally due to various factors and public perceptions about the single candidate in simultaneous elections. As rational human beings always have goals that reflect what is of interest in limited resources, and therefore 
people need to make choices. Someone in setting attitudes and actions to achieve an interest efficiently, he must choose between several alternatives and determine which options will bring the maximum benefits and usability to him.[12]

According to Niklas Luhmann[13] can be formulated as follows: 1) human action (human action) is an instrument so that human behavior can be explained as an effort to achieve a goal. Whether for individuals or a larger entity, these goals or values are hierarchically structured that reflects their preferences for what they want or need. Likewise, with the people of Sukarapih and Sodonghilir Villages in the simultaneous Pilkada they channel their voting rights by coming to the TPS, it shows as a business and is a form of their desire so that Tasikmalaya Regency can get leaders who can bring change and development to a better level, 2) the actors formulate their behavior through rational calculations about which actions will maximize their profits. Relevant information held by actors greatly influences the results of the calculations. When the elections took place, voters in Sukarapih Village used their rational calculations about what they should vote for in the ballot paper, which was between agreeing and disagreeing with the single candidate pair $\mathrm{Uu}$ Ruzhanul Ulum and Ade Sugianto being the regent again in charge of Tasikmalaya Regency. The community collects information and sees from the previous performance so that the information can represent their voice in determining the single partner to be the Regent and Deputy Regent again, 3) large-scale social processes including things such as ratings, institutions, and practices are the result of calculations. The elections that have been held on 9 December 2015 are the result of careful calculations or calculations that can be held.

In the Pilkada in Sukarapih Village on December 9, 2015 , based on the results of interviews with some resource persons, the Sukarapih village community expressed their perceptions about the elections with a single candidate, against the pair Uu Ruzhanul Ulum and Ade Sugianto, and revealed the reasons for their participation. This shows that a voter will use his rationality choices in determining who he thinks is appropriate to lead Tasikmalaya Regency by using calculations and considerations and evaluating the performance and achievements of the candidate pair.

A person who does not channel his voting rights when the election does not mean he does not use his rationality as a voter, but there are several reasons that he does not channel his rights. One of them is boredom and disappointment towards the candidate in terms of achievement and performance so that they even think of agreeing to nothing. But there are also some voters in Sukarapih Village who just choose and do not consider the pairs of candidates, they just come to obey government regulations and channel their voting rights.

Even so, it should be if the community does not agree with the existence of a single candidate, then the community must continue to channel their voting rights by coming to the polling station. Increasing community involvement in the holding of Regional Head Elections shows the strength of the democratic order in a country. Democracy requires the involvement of the people in every administration carried out by the state. The people are positioned as important actors in the democratic order, because in essence democracy is based on the logic of equality and the idea that the government needs approval from the governed. Community involvement is a basic element in democracy.

Motivation in choosing is very influential on a person's level of participation, and this is related to the identification of voters in the election. Particularly in the elections with a single candidate in Tasikmalaya Regency, the strength of candidates for regional heads and deputy regional heads became one of the determinants of voter interest in choosing candidates who were proposed even more so in the case in Tasikmalaya Regency the candidates were incumbent couples.

This means that the strengths and strengths of candidates and the issues proposed as campaign material become the basis of rational consideration for voters to determine their choice of votes. Rational identification of candidates or candidates who nominate themselves, in the form of characteristics of candidates, candidates' hopes and abilities to accommodate the interests of voters. Identification of figures can also be the basis for analyzing the results of imagery or favoring candidates in the election competition.

So it can be concluded, Pilkada is an abbreviation of regional head elections conducted directly by residents of local administrative areas who have met the requirements. The election of the regional head is carried out in one package together with the deputy regional head. Simultaneous elections this year have been held on Wednesday, December 9, 2015, where there are weaknesses and strengths. Simultaneous regional elections under Law number 8 of 2015 were designed to be more effective, efficient, cheaper and easier to handle when problems occur. But in the implementation process, many obstacles were ranging from the exchange of pilkada election logistics equipment to the presence of several single candidates in the simultaneous local election.

Community perception is very influential on the level of participation. Several reasons and factors caused the decline in the level of political involvement of the Sukarapih and Sodonghilir villagers during simultaneous regional elections with a single candidate. Among them: some of the people who did not distribute their voting rights were working outside the city; there are students who study outside the city; there is an elderly person who is not possible to come to the TPS but is still on the DPT list; there is a community that is truly apathetic, there is a busy life that really cannot be abandoned; there is only one candidate pair in the Pilkada so there is no variation; candidates who are less interested in the community or less calculated by the community so that the community is not enthusiastic, and some people do not agree with the existence of a single candidate. 


\section{CONCLUSION}

Based on the results of the research, conclusions can be drawn regarding the results of the study, namely: 1) the Simultaneous Regional Head Election which was held on December 9, 2015, gave rise to perceptions among the communities of Sukarapih and Sodonghilir Villages which were analyzed using rational choice theory on three macro phenomena, namely collective behavior, norms, and corporate actors. In terms of collective norms and behavior, the perception that the election with a single candidate is wrong and violates the rules/norms because the Sukarapih village community does not know the Constitutional Court's Decision Number: 100 / PUU-IIIV / 2015 dated September 29, 2015 concerning 1 (one) candidate pairs in the implementation of the Election of Regional Heads and Deputy Regional Heads simultaneously in 2015, 2) regarding corporate actors, elections with a single candidate seem to be forced. This is because those who are running for re-election as regents and vice regents are incumbent couples. If seen from the previous performance the candidate pair in his leadership period did not bring significant changes to the progress of Tasikmalaya Regency. For example, the HDI of Tasikmalaya Regency is very low, then the partiality of education is very lacking, infrastructure facilities and infrastructure are not by what is expected by the community. People who agree and channel their voting rights assume that if they do not vote, they will only waste the state budget for the implementation of the elections, 3) in simultaneous elections with a single candidate in Tasikmalaya District, there was a decline in the level of political participation in the community, namely the level of involvement in the election this time decreased by as much as $61.53 \%$. The level of the involvement decreased when compared with the previous General Election, namely the level of participation reached
$75 \%$. In this election, of the total voters as many as 4,253 and as many as 1,636 or around $38.46 \%$, preferring not to come to the polling station and not distribute their voting rights; 4) based on the pyramid of political participation described by Hinnebusch, the election with a single candidate for community participation is included in the category of apathy or passive involvement. The involvement of Sukarapih villagers in simultaneous local elections with their single candidates only obeys, accepts and carries out every government decision.

\section{REFERENCES}

[1] Mclaren P 2018 Liberatory Politics and Higher Education: A Freirean Perspective Revolutionary Multiculturalism Pedagogies Of Dissent For The New Millennium (Routledge) pp 42-75

[2] Friedmann J 2018 The active community: toward a political-territorial framework for rural development in Asia. Life Space and Economic Space (Routledge) pp 216-47

[3] R Gibbs G 2018 Analyzing Qualitative Data (SAGE)

[4] Flick U 2018 Designing Qualitative Research (SAGE)

[5] Kavanagh D 1983 Political Science and Political Behaviour (Unwin Hyman)

[6] Surbakti R 1992 Memahami Ilmu Politik (Grasindo)

[7] Evans J A J 2004 Voters and Voting (London: SAGE Publications)

[8] Knoke D 2000 Changing Organizations: Business Networks In The New Political Economy (New Perspectives in Sociology) (Perseus)

[9] Thompson N 2016 Anti-Discriminatory Practice: Equality, Diversity and Social Justice (Practical Social Work Series) (Basingstoke, United Kingdom: Palgrave Macmillan)

[10] Hinnebusch R A 2017 Political parties in MENA: their functions and development Br. J. Middle East. Stud. 44 159-75

[11] Oser F K 2014 Toward a Theory of the Just Community Approach: Effects of Collective Moral, Civic, and Social Education Handbook of moral and character education ed L Nucci, D Narvaez and T Krettenauer (Routledge) pp 214-38

[12] Budiardjo M 2008 Dasar-Dasar Ilmu Politik (Jakarta: Ikrar Mandiriabadi)

[13] Luhmann N 2017 Trust and Power (John Wiley \& Sons Inc). 